\title{
ADAPTATION OF TURKEY'S REGIONAL POLICIES TO THE EU ACQUIS: AN EVALUATION THROUGH PROGRESS REPORTS
} (1998-2012)

\author{
Onur SUNGUR* \\ Hidayet KESKIN ${ }^{* *}$ \\ Murat Ali DULUPÇ $\mathbf{U}^{* * *}$
}

\begin{abstract}
Regional disparities, as in every country, represent one of the basic problem areas in Turkey. Although regional policy has always been given importance in the five-year development plans, regional disparities still remain as a fundamental problem in Turkey. According to the data of year 2001 (the latest data available at the provincial level), there is a huge income differences among the provinces as much as eleven times. This situation is not much different at the regional level. But recently Turkey has entered a new route with the EU accession process and has experienced a transformation process in regional development in terms of both theory and practice. Considering the recent practices in the field of regional development, it is seen that the concept of 'old regionalism' was abandoned and the 'new regionalism' approach has begun to be adopted through focusing on the concepts such as R\&D, innovation, clusters and new industrial spaces. Legal/institutional regulations related to the acquis have accelerated in the field of regional development when Turkey's candidacy status was declared after the 1999 Helsinki Summit.

In this study, the transformation in regional development in Turkey within the process of the EU will be examined. First Turkey's development plans and regional policies will be reviewed. Then, acquis of EU regional policy, the structural funds and documents will be examined critically, particularly referring to Progress Reports. Finally, efforts with respect to adaptation to acquis will be evaluated and the route which Turkey will/must follow in case of EU membership will be discussed.
\end{abstract}

Keywords: Regional Development, Regional Policy, Development Plans, Turkey, Progress Reports

\footnotetext{
* Assist.Prof.Dr., Mehmet Akif Ersoy University, Department of Economics, e-mail: onursungur@mehmetakif.edu.tr

** Assist.Prof.Dr., Suleyman Demirel University, Department of Economics, e-mail: hidayetkeskin@sdu.edu.tr

${ }^{* * * *}$ Prof.Dr., Suleyman Demirel University, Department of Economics, e-mail: muratdulupcu@sdu.edu.tr
} 


\section{TÜRKIYY'NIN BÖLGESEL POLITIKALARININ AB MÜKTESEBATINA UYUMU: İLERLEME RAPORLARI ARACILIĞIYLA BİR DEĞERLENDİRME (1998-2012)}

\section{Özet}

Bölgesel farkllliklar, her ülkede olduğu gibi, Türkiye'de de en önemli sorunlardan birini teşkil etmektedir. Beş Yıllık Kalkınma Planları'nda bölgesel politikalara önem verilmesine rağmen, bölgesel farklılıklar Türkiye'de hala temel sorun olarak durmaktadır. 2001 yll verilerine (il düzeyindeki en son veriler) göre, iller arasında 11 kat fark bulunmaktadır. Bu durum bölgesel düzeyde de pek farklı değildir. Ancak son zamanlarda Türkiye AB üyeliği ile birlikte yeni bir rotaya girmiştir ve hem teori hem de uygulama açısından bölgesel gelişmede bir dönüşüm yaşamaktadır. Bölgesel gelişmedeki son uygulamalar dikkate alındiğında, "eski bölgeselcilik" yaklaşımının terk edildiği ve AR-GE, inovasyon, kümelenmeler ve yeni endüstriyel alanlar gibi "yeni bölgeselcilik" yaklaşımının benimsendiği görülmektedir. Türkiye’nin adaylı̆̆ının açıklandı̆̆ 1999 Helsinki Zirvesi sonrasında bölgesel gelişme konusundaki müktesebata ilişkin yasal/kurumsal düzenlemeler de hızlanmıştır.

$B u$ çallşmada, AB sürecinde Türkiye'de bölgesel gelişmedeki dönüşüm incelenecektir. Öncelikle, Türkiye'nin kalkınma planlart ve bölgesel politikaları ele alınacaktır. Ardından, AB bölgesel politika müktesebatı, yapısal fonlar ve kritik dokümanlar, özellikle İlerleme Raporları bağlamında incelenecektir. Son olarak, müktesebata uyum să̆lanmasina yönelik çabalar değerlendirilecek ve AB üyeliği durumunda Türkiye'nin izleyeceği / izlemesi gereken rota tartışllacaktır.

Anahtar Kelimeler: Bölgesel Gelişme, Bölgesel Politika, Kalkınma Planları, Türkiye, Ilerleme Raporlarl

\section{Introduction}

Regional disparities, as in every country, represent one of the basic problem areas in Turkey. Although regional policy has always been given importance in the five-year development plans which had been introduced during the beginning of planned economy period, regional disparities still remain as a fundamental problem in Turkey. According to the data of year 2001 (the latest available data at the provincial level), there is a huge income differences among the provinces as much as eleven times. For example, while the most developed province Kocaeli has $\$ 6165$ per capita GDP, Ağrı has \$568 per capita GDP. This situation is not much different at the regional level. But recently Turkey has entered a new route with the 
EU accession process and has experienced a transformation process in regional development in terms of both theory and practice.

Turkey's accession process towards the European Union is one of the most important determinants in Turkish policymaking mentality and one can see the effects of this process easily on each policy field. While Turkey tries to adopt the European acquis, it also tries to become closer to the European structures and practices of regional and local economic policy. And the most vital economic impact of the EU membership will on regional policy, even though there has been little concern in public opinion and policy circles about regional policy.

On 3 October 2005, membership negotiations were symbolically opened with Turkey, which has been an associate member of the EU since 1963 and an official candidate since 1999. The historical decision on 17 December 2004 by the European Council was confirmed by the European heads of state and government on 17 June 2005. On 29 June, the Commission presented its negotiating framework to Ankara; and following intense negotiations, the EU-25's foreign ministers finalized the document on 3 October. Within hours, Turkey accepted the terms (EC, $2005 \mathrm{a} ; 2005 \mathrm{~b} ; 2005 \mathrm{c})$. In the June of the following year, the de facto negotiation process was initiated between the parties.

Legal/institutional regulations related to the acquis have accelerated in the field of regional development when Turkey's candidacy status was declared the after the 1999 Helsinki Summit. First of all, in 2002, the new regional classification was introduced compatible with the EU's NUTS (Nomenclature of Territorial Units for Statistics) classification in Turkey by the Law No 2002/4720. Another important step is the introduction of Regional Development Agencies (RDAs) in Turkey by the Law No 5449. In addition, Turkey has given the change to benefit the Instrument for Pre-Accession Assistance (IPA) with the beginning of negotiations in $3^{\text {rd }}$ October 2005. However, Turkey cannot use the EU's Structural Funds which is the biggest source of regional development yet Turkey is not a full member. Turkey will take an opportunity to benefit these funds when the membership is completed and enter an important period. For this reason, the most important impact of Turkey's membership of the EU will be seen in the field of regional development thanks to using Structural Funds.

Prepared in this specific contextual atmosphere, this article aims at scrutinizing the nature of the EU-driven regional policy changes in Turkey and assessing the extent to which these changes can be put into practice by Turkey, to be functional in confronting regional economic disparities in the country. In this context, firstly, Turkey's five-year development plans and regional policies and regional policy changes in these policies will be reviewed. Then, acquis of EU regional policy and Turkey's progress on the adoption of EU's regional policy will be examined 
critically, particularly referring to Progress Reports. In this regard, Turkey's Regular Reports (1998-2004) and Progress Reports (2005-2012) and Turkey's position on the adoption to the acquis will be evaluated. Finally, efforts with respect to adaptation to acquis will be evaluated and the route which Turkey will/must follow in case of EU membership will be discussed.

\section{Transformation in Regional Policy: Understanding 'New Regionalism'}

Although there are various classifications regarding evolution of regional policies, Soja (2009: 259), as a mainstreaming scholar, has classified the evolution of regional planning and regional development theories in four phases in historical perspective:

- 1920-1950: early approaches which focused on resource development and environmental preservation

- 1950-1980: welfare regionalism, which aims at efficient and equitable economic development at national scale

- After 1980s: highly competitive entrepreneurial regionalism based on neoliberal ideas

- After 1990s: Contemporary development of a new regionalism as the foundation for a new approach to regional planning and regional development theory.

The first and second phases of literature on regional development theory and policy, and tools used for the implementation of those policies assumed regions as passive, pre-given and pre-defined territories (Amin \& Thrift, 1994; Burfisher, Robinson \& Thierfelder, 2004). Considering the recent practices in the field of regional development, it is seen that the concept of 'old regionalism' was abandoned and the 'new regionalism' (Keating, 1998; Lovering, 1999) approach has begun to be adopted through focusing on the concepts such as R\&D, innovation, clusters and new industrial spaces. This new approach has become prominent issue in the field of economic geography and has begun to inform and frame key aspects of regional policy (Webb \& Collis, 2000: 862; Tomaney \& Ward, 2000: 472, Hettne, 2005: 543).

Today, as ongoing main trends, the technological development and globalisation are transforming regions into dynamic, pro-active, entrepreneurial, continuous spatial network geographies (Amin \& Thrift, 1995). This transformation was mainly driven by economic change, globalization and European integration, and the transformation -even the 'end' (Ohmae, 1995)- of (nation) state. In this process, regions and localities have emerged as key sites of economic change and can be seen as local production systems rather than simply the location of economic activities. 
Lovering (1999: 379) identifies two main characteristics of 'new regionalism', which are: (1) the 'region' is becoming the 'crucible' of economic development, (2) the 'region' should be the prime focus of economic policy. The status gained by the regional scale makes regions as pro-active and active entities which led to a rise of a series of principles which would have meaning at the local level, such as sustainability, social inclusion, human resources development, and of course governance (Florida, 1995). In this context, the key concepts of 'new regionalism' approach can be summarized as (OECD, 2009a: 2; 2009b: 69):

- a focus on endogenous assets (such as infrastructure, education, human capital, innovation, geographic characteristics), rather than exogenous investments and transfers

- an emphasis on opportunity rather than on disadvantage

- a collective / negotiated governance approach, involving national, regional and local government plus other stakeholders, with the central government playing a less dominant role.

Table 1: The 'Old' and 'New' Regionalism

\begin{tabular}{|l|l|}
\hline 'Old' Regionalism & 'New' Regionalism \\
\hline Government & Governance \\
\hline Coordination & Collaboration \\
\hline Accountability & Trust \\
\hline Centralized & Decentralized \\
\hline Hierarchical & Multi-Level \\
\hline Top-to-bottom approach / & $\begin{array}{l}\text { Bottom-to-top approach / } \\
\text { Tailor-Made }\end{array}$ \\
\hline Standardized & Inclusive Projects \\
\hline Elite Projects & Active Regions \\
\hline Administrative Regions & All Regions \\
\hline Less Developed Regions & Growth \\
\hline Balancing Regional Disparities & $\begin{array}{l}\text { Public-Private Partnership } \\
\text { (PPP) }\end{array}$ \\
\hline Public Measures & Long Term (Sustainability) \\
\hline Short Term & \\
\hline
\end{tabular}

Source: Dulupçu, 2006: 246.

Among others, the failure of the large scale public investments and the state-led policies which aimed at developing less prosperous regions have caused to rise of new regionalism. The older generation of regional policies, generally utilized either attracting inward investments or the large infrastructure investments to certain locality as tools to develop a region. Thus one-fits-all method has been accepted among policy circles. This new regional approach is based on the principle that all regions have their own growth opportunities and all regions can reach their growth potentials through inside. In this process, regions should wake up their own local 
assets to grow, rather than depending on national transfers and subsidies. In this approach, knowledge production capacity, innovativeness, well-educated population, connection to global markets, business-friendly environment and infrastructure system and well-functioning labour system are seen as a source of regional growth and competitiveness (OECD, 2009a: 2). And also the strategic coordination at the regional level is also important for economic growth (Webb \& Collis, 2000: 860).

\section{Evolution of Regional Policies in Turkey}

As the evolution of its economic development, Turkey displays an understanding of regional development conceived in terms of a 'residual' category (Dulupçu, 2005). This can be observed in the regional policy of the central government, where the State Planning Organization (SPO) ${ }^{1}$ ultimately sees centrally-led and controlled regional economic development as an activity designed only for less-developed provinces. This has resulted not only from the nature of the administrative system or state-centred foundations of the Republic, but also from the prioritization of national economic problems -like the industrialization of the 1960s or the macroeconomic stability of the 1990s. (Öniş \& Webb, 1994; Göksu, 2000; Emek, 2004).

- Turkey's regional development history can be summarized in three different periods:

- The first period covers the period from the beginning of the Republic (1923) until the start of the planned development era. In this period, regional planning approach was 'construction' rather than 'development'. Regional development had been almost neglected until the planned era.

- The second period starts with the introduction of the 1st FYDP (Five Year Development Plan) in 1963. Turkey has been put into practice totally nine FYDPs since 1963. These plans are prepared by the SPO, which is the central administration responsible for national and regional planning and regional policy. Most of these plans could not be implemented effectively. The main reason of this situation is the absence of any regional administrative structure at the intermediate level between central government and the local authorities. Similarly, the success of rural development projects -such as Antalya, Çukurova and Zonguldak regions- has been limited due to the financial and organizational problems. (Loewendahl-Ertugal, 2005: 26).

- The third period starts basically with the acceleration of the EU integration process when Turkey's formal candidacy status is accepted in Helsinki Summit in 1999. Following this, the EU financial assistance along with acquis has forced the central thinking towards a local understanding. This is partly confessed in Preliminary

\footnotetext{
${ }^{1}$ Recently retitled as Ministry of Development
} 
National Development Plan-PNDP (DPT, 2003a), 9th Development Plan (DPT, 2007: 57) and Accession Partnership Document (DPT, 2003b).

Turkey has used mainly four tools for regional development policy: regional plans, priority development areas, provincial development plans, and national development plans (DPT, 2008: 9). Turkey had regional policies but not regional development administrations until 2006 because largely of its possible implication for separatism. Recently, as a reflection of EU membership process, the regional development plans by the Regional Development Agencies (RDAs) were added to that list (Dulupçu, Gül \& Okçu, 2013: 275-276).

The regional dimension has always been in a central position in the development efforts of Turkey which can be obviously seen from FYDPs (DPT, $1985 ; 1990 ; 1996 ; 2000 a)$. The planning approach based on regional disparities took place in all FYDPs (between 1962 and 2001 eight plans were prepared). As it can be seen in Table 2, from the first plan to the last one, regional disparities have always been among the main problem to be dealt with. However, one cannot see an integrated policy approach to regional development throughout the planning periods on the whole, except for the previous 8th FYDP, which employed, although in a limited manner, strategic and participatory principles and approaches of planning (DPT, 1962; 1967; 1972; 1978; 1985; 1990; 1996; 2000a). 
Table 2: Regional Policies in Five-Year Development Plans

\begin{tabular}{|c|c|c|c|c|}
\hline Plans & Principles & $\begin{array}{l}\text { Approaches and } \\
\text { policies }\end{array}$ & Targets & Instruments \\
\hline 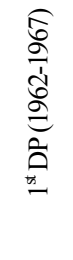 & $\begin{array}{l}\text {-Increasing } \\
\text { influence of } \\
\text { economic } \\
\text { development on } \\
\text { the regions } \\
\text {-Regional } \\
\text { economic } \\
\text { integration }\end{array}$ & $\begin{array}{l}\text {-Regional planning } \\
\text {-Growth poles (e.g. } \\
\text { East Marmara, } \\
\text { Çukurova, Antalya, } \\
\text { Zonguldak) }\end{array}$ & $\begin{array}{l}\text {-Balanced } \\
\text { urbanization and } \\
\text { regional public } \\
\text { service \& income } \\
\text { distribution } \\
\text { - Investment } \\
\text { efficiency }\end{array}$ & $\begin{array}{l}\text {-Financial incentives } \\
\text { - Alternatives measures } \\
\text { depending on investment in less } \\
\text { favoured regions }\end{array}$ \\
\hline 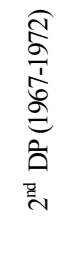 & $\begin{array}{l}\text {-Focusing on } \\
\text { population } \\
\text { problems } \\
\text { stemmed from } \\
\text { rapid } \\
\text { urbanization }\end{array}$ & $\begin{array}{l}\text {-Regional or/and } \\
\text { provincial planning } \\
\text {-Indirect regional } \\
\text { planning }\end{array}$ & $\begin{array}{l}\text {-Balanced inter- } \\
\text { regional } \\
\text { development } \\
\text {-Balanced (social } \\
\text { equity) distribution } \\
\text { between regions } \\
\text { - Investment } \\
\text { efficiency }\end{array}$ & $\begin{array}{l}\text {-Tax reductions } \\
\text {-Financial incentives toward } \\
\text { private investments } \\
\text {-Pilot projects } \\
\text {-Keban (Second biggest dam in } \\
\text { Turkey) }\end{array}$ \\
\hline 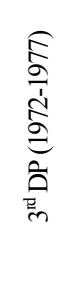 & $\begin{array}{l}\text {-Alleviation of } \\
\text { regional } \\
\text { disparities } \\
\text {-Development of } \\
\text { particular less } \\
\text { favoured regions }\end{array}$ & $\begin{array}{l}\text {-Sectoral and } \\
\text { provincial planning }\end{array}$ & $\begin{array}{l}\text { Same as in the } \\
\text { second plan }\end{array}$ & $\begin{array}{l}\text { - Financial incentives } \\
\text {-Industrialization programmes for } \\
\text { less favoured regions } \\
\text {-Inventory of local assets } \\
\text {-Provincial planning } \\
\text {-Sectoral planning } \\
\text {-'Packet projects' } \\
\text {-Priority Provinces for } \\
\text { development }\end{array}$ \\
\hline 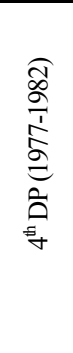 & $\begin{array}{l}\text {-Mobilization of } \\
\text { all resources to } \\
\text { solve regional } \\
\text { problems }\end{array}$ & $\begin{array}{l}\text {-Empowerment of } \\
\text { inter-sectoral and } \\
\text { inter-regional } \\
\text { connections }\end{array}$ & $\begin{array}{l}\text {-Development of } \\
\text { geographically less } \\
\text { favoured regions } \\
\text {-Regional and } \\
\text { sectoral mutual } \\
\text { dependency } \\
\text {-Spatial organization }\end{array}$ & $\begin{array}{l}\text {-Interest rate reductions for } \\
\text { investments } \\
\text {-Various financial aids } \\
\text {-To publish necessary measures } \\
\text { for various sectors and regions } \\
\text {-'Packet projects' } \\
\text {-Investments in provinces and } \\
\text { regions } \\
\text {-Çukurova Urban Development } \\
\text { project } \\
\text {-GAP (DPT-JICA) }\end{array}$ \\
\hline
\end{tabular}




\begin{tabular}{|c|c|c|c|c|}
\hline 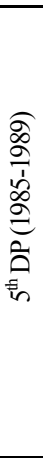 & $\begin{array}{l}\text {-To accelerate } \\
\text { development } \\
\text { rationalization of } \\
\text { resource using in } \\
\text { less favoured and } \\
\text { sectorally high } \\
\text { potential regions }\end{array}$ & $\begin{array}{l}\text {-Direct regional } \\
\text { planning, including } \\
\text { studies of regional } \\
\text { effects of projects } \\
\text { (proposal of } 16 \\
\text { functional regions ) }\end{array}$ & $\begin{array}{l}\text {-Regionally } \\
\text { balanced } \\
\text { development } \\
\text { depending on social } \\
\text { equity }\end{array}$ & $\begin{array}{l}\text {-Scheduling of regional } \\
\text { development tables for } \\
\text { determination of potential } \\
\text { resources } \\
\text {-Choosing relevant investments } \\
\text { according to above-mentioned } \\
\text { tables } \\
\text {-To provide infrastructures for } \\
\text { industrial projects pre-determined } \\
\text { in line with prioritized regions and } \\
\text { relevant sectors } \\
\text {-Financial aids for investments in } \\
\text { Priority Provinces for } \\
\text { development }\end{array}$ \\
\hline 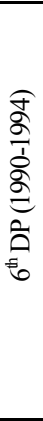 & $\begin{array}{l}\text {-Integration of } \\
\text { social, } \\
\text { administrative, } \\
\text { legal and } \\
\text { financial } \\
\text { dimensions for } \\
\text { implementation } \\
\text {-Adaptation of } \\
\text { statistical system } \\
\text { in line with the } \\
\text { EU and } \\
\text { international } \\
\text { standards }\end{array}$ & $\begin{array}{l}\text {-Planning at regional } \\
\text { and sub-regional } \\
\text { level }\end{array}$ & $\begin{array}{l}\text {-Balanced growth in } \\
\text { regions } \\
\text {-Supporting sub- } \\
\text { districts to prevent } \\
\text { migration from } \\
\text { villages towards } \\
\text { cities }\end{array}$ & $\begin{array}{l}\text { - Increasing the amount of } \\
\text { available financial resources for } \\
\text { Priority Provinces for } \\
\text { development and state support } \\
\text {-Incentives for private sector in } \\
\text { Priority Provinces for } \\
\text { development and establishment of } \\
\text { a special fund for this aim } \\
\text {-Industrial districts }\end{array}$ \\
\hline 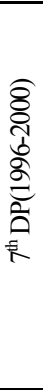 & $\begin{array}{l}\text {-Integration of } \\
\text { sectoral and } \\
\text { spatial analysis } \\
\text {-Sectoral } \\
\text { specialization of } \\
\text { cities } \\
\text {-City planning } \\
\text {-Alleviation of } \\
\text { regional } \\
\text { disparities } \\
\text {-Strengthening } \\
\text { competitiveness }\end{array}$ & $\begin{array}{l}\text {-Regional and sub- } \\
\text { regional projects } \\
\text {-Mobilization of } \\
\text { regionally embedded } \\
\text { competences } \\
\text {-Sustainable } \\
\text { development }\end{array}$ & $\begin{array}{l}\text {-Rationalization of } \\
\text { both demographic } \\
\text { change and } \\
\text { migration } \\
\text {-To analyse } \\
\text { metropolitan } \\
\text { problems in a } \\
\text { separate category } \\
\text {-Policy development } \\
\text { for housing } \\
\text { problems } \\
\text {-Regional disparities }\end{array}$ & $\begin{array}{l}\text { - To continue the implementation } \\
\text { of Priority Provinces for } \\
\text { development } \\
\text {-Emergency Support Programme } \\
\text { to East and Southerneast Anatolia } \\
\text {-GAP } \\
\text {-Legal measures } \\
\text {-Housing projects } \\
\text { - Supporting SME's in Priority } \\
\text { Provinces for development } \\
\text {-ZBK, Yeşilırmak Basin, } \\
\text { DOKAP, DAP }\end{array}$ \\
\hline 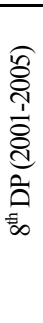 & $\begin{array}{l}\text {-Participatory } \\
\text { planning } \\
\text {-Sustainability } \\
\text {-Rationalization } \\
\text { in the use of } \\
\text { resources } \\
\text {-Adaptation to } \\
\text { the EU regional } \\
\text { development } \\
\text { policies }\end{array}$ & $\begin{array}{l}\text {-Regional planning } \\
\text { from a strategic } \\
\text { perspective } \\
\text {-Clustering } \\
\text {-Provincial } \\
\text { Development Plans }\end{array}$ & $\begin{array}{l}\text {-Enhancing } \\
\text { competitiveness } \\
\text {-Local } \\
\text { entrepreneurship and } \\
\text { mobilization of local } \\
\text { resources } \\
\text {-Regional disparities }\end{array}$ & $\begin{array}{l}\text {-SME's supports } \\
\text {-EU funds } \\
\text {-First comprehensive regional } \\
\text { plans } \\
\text {-Human capital investments }\end{array}$ \\
\hline
\end{tabular}

Source: DPT, 1962; 1967; 1972; 1978; 1985; 1990; 1996; 2000a; OECD, 1986: 5; $1988: 8$. 
However the limited availability of public financial resources for regional development along with non-existence of regional strategic plans -prepared through a participatory approach and priority determination- and regional programmes depending on those strategic plans, caused to a limited regional support from the regional actors. Consequently we have observed poor performance in regional development which has been directed through centrally designed and implemented regional development tools.

One can rationalize centrally planned regional development by putting forward the high degree of disparities among the geographical regions and the provinces in Turkey. With respect to the geographical regions, the socioeconomic divide between western and eastern Turkey is at an unacceptable level. According to the data of year 2001, there is a huge income differences among the provinces as much as eleven times. This situation is not much different at the regional level. For example, according to an available per capita GNP index data study for the period 1983-1998, while Turkey has an index value 100, the Marmara Region (the most prosperous region in the west) has an index value of 156 and for the Eastern Anatolia Region (the less prosperous region in the east) this figure remains at 41 . The numbers are even worse at the provincial level. For instance, the index value is 168 for the province of Kocaeli, and 24 for Van (DPT, 2003c). To put it in other words: "whereas the eastern half of the country accounts for 37 percent of the population, its share of GNP is only 22 percent. In contrast, the western part of the country, with 63 percent of the population accounts for 78 percent of GDP. GDP per capita ratio is 60 for eastern Turkey and 123 for western Turkey' (Reeves, 2005: 2).

\section{Turkey's Regionalism: A Brief Evaluation of Progress Reports}

\subsection{General Framework of EU's Regional Policy}

The $2^{\text {nd }}$ and $3^{\text {rd }}$ articles of the constituting Treaty of Rome envisages that 'to develop social protection, employment level and economic activities in the Community through a coherent, harmonized balanced and sustainable manner...to increase life standard and life quality, and to realize economic and social cohesion'. In addition to this, articles from 158 to 162 which emphasis 'economic and social cohesion' state the purpose of diminishing disparities among different regions (including rural areas, less developed regions and islands) in the Community. The EU realizes the aim of cohesion through the actions of the Structural Funds. In this regard the Commission evaluates the performance of actions for achieving economic and social cohesion through a report for every three year, and these reports also suggest new proposals for the future regional policy actions (Avrupa Komisyonu Türkiye Temsilciliği, 2000). 
In the EU, regional disparities in terms of development level and life standards have always been regarded as a regional issue that should be dealt with, by member states. However political and economic cohesion have necessitated a fight against regional disparities. Although there exists a certain focus on the problem of 'regional disparities' in the EU that led to significant progress in alleviating disparities, the most prosperous 10 regions' GDP per capita is still three times higher than that of the least prosperous 10 regions (IRE, 2004). According to the EU, balancing regional economies is crucial in order to benefit from single market opportunities and the EMU. In this line Community spent some 213 billion Euros on Regional policy issues particularly on the least developed regions for the Budget period 2000-2006 which is nearly equivalent to one third of the total budget (Avrupa Komisyonu Türkiye Temsilciliği, 2000). For the budget period the allocation amount to the target regions through different funds will be 347 billion Euros. After the Common Agricultural Policy (CAP), the regional policy of the EU is the second largest item of the EU budget.

The $21^{\text {st }}$ chapter in the acquis (in the screening process it is redefined as chapter 22) is called 'Regional Policy and the Coordination of Structural Instruments'. Under this chapter the procedures, methods, documents, legislative regulations, and the framework of Structural and Cohesion Funds are specified. The chapter as well includes assistance types and methods for new member states and candidates. Moreover, the eligibility of regions, new assistance types, and new initiatives are also mentioned in this chapter (Başbakanlık, 2003; EC, 1998-2004).

The acquis under this chapter consists mostly of framework and implementing regulations, which do not require transposition into national legislation. They define the rules for drawing up, approving and implementing Structural Funds and Cohesion Fund actions. These programmes are negotiated and agreed with the Commission, but implementation is under the responsibility of the Member States. It is essential that Member States respect Community legislation in general, for instance in the areas of public procurement, competition and environment, when selecting and implementing projects, and have the necessary institutional structures in place to ensure implementation in a sound and cost-effective manner from the point of view of both management and financial control (Dulupçu \& Sungur, 2006; Brasche, 2001).

As mentioned before, the regional policy is the second largest item of the EU budget. That means, although there is no compulsory directive or need about the transfer of the acquis on regional policy and structural instruments to internal legislation, regional policy will provide the largest financial assistance, and thus will contribute to national economic growth more than any other chapter of the acquis. 


\subsection{Turkey's Progress on the Adoption to EU's Regional Policy}

One of the perspectives to assess the evolution and development of regional policies in Turkey is the EU methodology for overall assessment towards the acquis. This formal process represents itself in two documents: the regular reports that covered candidacy status and secondly the progress reports which has covered and will cover negotiation period, namely steps to adapt the acquis. The EU approach to Turkey in terms of regional policy has always been critical yet regional issues have been one of the weakest chains of policy design and formation. However this approaching also indicates the importance of regional policy as a tool for accessing structural funds which will impose the greatest impact on Turkey and on its socio-economic development. Interestingly such a great impact has been minor concern in political circles until recently due to heavily shift to the Copenhagen criteria, leaving this so-called technical dimension alone. Actually the issues like the democratization, rule of law and marketization in Turkey have found strong voice both in Turkey and in Europe. Turkish public circles found these issues attractive at least in two dimensions. The first is making the EU as an anchor to reform; the second is the political discourse in which the opposition and ruling parties can gain competitive advantages through debating each other. On the European side, the deficits in civil society have played an important role to suppress full membership in a foreseen period of time.

In this regard a brief evaluation of these reports (between 1998 and 2012) can serve us to understand regional dimension of the acquis and the Turkey's position in regional governance and development. Nonetheless one should bear in mind the weakness of regional policy in Turkey. 
Table 3: Turkey's Progress on Implementation of EU Regional Policies

\begin{tabular}{|c|c|c|c|c|c|c|c|}
\hline & 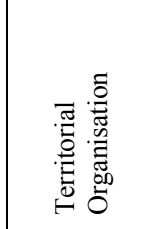 & 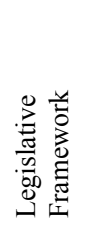 & 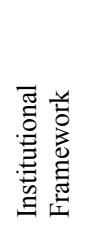 & 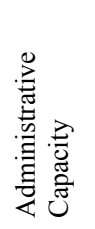 & 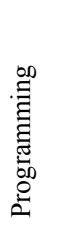 & 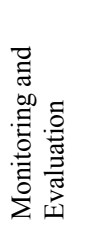 & 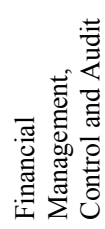 \\
\hline 1998 & - & - & - & - & - & - & - \\
\hline 1999 & - & - & - & - & - & - & - \\
\hline 2000 & NP & NP & NP & NP & NP & - & - \\
\hline 2001 & - & NP & NP & - & NP & NP & NP \\
\hline 2002 & SP & NP & NP & - & NP & NP & NP \\
\hline 2003 & SP & NP & SP & - & SP & NP & NP \\
\hline 2004 & NP & SP & SP & - & SP & SP & SP \\
\hline 2005 & NP & LP & LP & SP & NP & NP & SP \\
\hline 2006 & NP & SP & NP & LP & SP & GP & SP \\
\hline 2007 & - & SP & SP & LP & GP & NP & SP \\
\hline 2008 & - & SP & LP & LP & GP & SP & SP \\
\hline 2009 & - & SP & SP & LP & SP & LP & LP \\
\hline 2010 & - & SP & SP & SP & SP & SP & SP \\
\hline 2011 & - & NP & SP & SP & GP & SP & SP \\
\hline 2012 & - & SP & SP & SP & SP & SP & SP \\
\hline $\begin{array}{l}- \text { The } \\
\text { NP } \\
\text { LP } \\
\text { SP } \\
\text { GP }\end{array}$ & $\begin{array}{l}\text { re is no such } \\
\text { No Progress } \\
\text { Limited / Ve } \\
\text { Progress / S } \\
\text { Good Progre }\end{array}$ & $\begin{array}{l}\text { eak Pro } \\
\text { Progress }\end{array}$ & & & & & \\
\hline
\end{tabular}


First of all, it can be seen that neither radical nor incremental progress has been achieved until 2002 for the harmonization of Turkey's regional policies to EU regional policy (see Table 3). Although Turkey is an 'official candidate' since 1999, we see that there was no progress between 1998 and 2001 in none of the titles that discussed in the report, namely territorial organization, legislative framework, institutional framework, administrative capacity, programming, monitoring and evaluation, financial management, control and audit. Following 2002, Turkey has been criticized in the EC Progress Reports that only limited progress has been achieved at least in one or more areas. For example, there is only progress in 2002, which is in the area of territorial organisation that is the introduction of the definition of NUTS system. The favourable statements can be found in 2003 Progress Report, relating to NUTS system (about the establishment of 26 NUTS Level 2 regions with Law No: 2002/4720). However, there is no progress in this area (territorial organization) since 2003 apart from NUTS system. Looking closer to the field of legislative framework and institutional framework, it is mentioned by the EC Regular Reports that Turkey has made some progress after 2004. In addition, it is seen that the progress has accelerated in all fields in recent years. Especially there is a good progress in all areas in 2010 and 2012.

Secondly; Turkey has made progress mostly in the areas of Programming, Financial Management, Control and Audit, Legislative Framework and Institutional Framework about the harmonization of the acquis. Regarding territorial organization, there is no progress except NUTS classification, as mentioned before. However, there has no evaluation in this area about Turkey's progress since 2006 because there is no such a title in Progress Reports following 2006. Furthermore, Turkey has shown little progress in Administrative Capacity. The achievement in this area has seen as limited by EC. However, the developments about administrative capacity between 2010 and 2012 are satisfactory as mentioned in related Progress Reports. The reports can be analyzed in two periods: candidacy and negotiation periods.

\subsubsection{Candidacy Period (1998-2005)}

The very first report, namely 1998 Regular Report, basically aims to define regional disparities in Turkey, referring to less developed regions and West-East divide. In this report no detailed assessment about Turkey's progress and performance on regional policies were given because of the lack of information from the Turkish authorities. Turkey's regional disparities are criticized and it is mentioned that Turkey's development lags well behind the Community average and it is essential for both sides to implement an effective structural policy (EC, 1998: 50). Obviously the report has no concrete offers for the solution of regional disparities. 
Similar expressions of the 1998 Regular Report can be found in 1999 and 2000 Regular Reports which had stressed that Turkey is experiencing the most acute regional problems (EC, 1999: 40; 2000: 30). Progress report is informed that Turkey would have to adapt its central administration in order to address this priority in allocating significant human and budgetary resources in this area, improving administrative procedures and establishing operational structures in the regions. However all these suggestion are known by the central government and criticisms seem to be polite without any radical policy implications.

In 2000 Progress Report, there is a criticism that there is no significant progress on regional policies since from the last regular report (EC, 2000: 59). There are lots of critics and suggestions about territorial organisation, legislative framework, preparation for programming, administrative capacity. Most important of all, concerning territorial organization, it is advised that Turkey needs to propose to the Commission a NUTS classification in accordance with Community rules.

In 2001 Progress Report, the criticism has been worsening. In the report, it is mentioned that no developments has been reported and no further progress has been made about legislative framework, institutional structures, programming, monitoring and evaluation, financial management and control (EC, 2001: 77). In the report, as an achievement, it is mentioned that the SPO and the State Institute of Statistics have started to prepare a NUTS classification in accordance with Community rules.

In 2002, the first major development about the implementation of EU's regional policy has been achieved, namely the introduction of NUTS System. This was also mentioned in the 2002 Regular Report (EC, 2002: 109) and it is signed that this situation has been represented a first substantial step towards the comparability of Turkish regional statistics with the statistics from other regions in Europe. However, it is once again criticized that there is no progress in the fields of legislative framework, institutional structures, programming, monitoring and evaluation, financial management and control. Additionally, it is stressed that Turkey still needs to develop the structures necessary for the organisation and the implementation of the structural policies.

In 2003 Progress Report, there is some progress regarding territorial organisation, institutional structures, and programming. The issues highlighted in the report are that the approval of NUTS classification (with Law No: 2002/4720), the establishment of new department in the SPO (about pre-accession programmes) and the preparation of a National Development Plan for 2004-2006 period. It is stated that no developments are to be reported in the fields of legislative framework, monitoring and evaluation, financial management and control (EC, 2003: 104-105). 
In 2004 Regular Report, it is criticised that very limited developments are made in the area of regional policy since from the last report. Looking in detail, no progress about territorial organisation has been done and some progress about legislative framework, institutional structures (establishment of service unions in some regions to form a NUTS Level 2 unit), programming (approval of PNDP), monitoring and evaluation, financial management and control have been achieved. However, these developments regarded as insufficient and it is noticed that regional development structures at regional level remain weak in Turkey (EC, 2004: 132). It is advised that Turkey should establish the bodies and mechanisms needed to implement the acquis.

On the other hand, the candidacy status also includes a worthwhile financial dimension Turkey was not supported through the PHARE, ISPA and SAPARD funds, from which the previous candidate countries benefit (these programmes were abolished and replaced with IPA). In 2000-2006 period, Turkey was supported by the EU funds that are aggregated under the headline of 'Pre-Accession Financial Assistance for Turkey'. In this period, funds were allocated mainly for capacity building projects and legal and institutional regulations on the adaptation of the acquis in membership process. In 2002-2006, a total of 1.3 billion Euros was allocated to Turkey for total 164 projects (Ministry for EU Affairs, 2012: 7).

\subsubsection{Negotiation Period (2005-2012)}

On 3 October 2005, membership negotiations were symbolically opened with Turkey and the effect of this development on the progress in regional policies can be seen in subsequent progress reports.

In 2005 Progress Report, Turkey is criticized because there is no progress about territorial organisation and NUTS Level 2 regions do not correspond to any administrative structures. At the same time, it is criticized that no development is seen on the legal framework for the establishment of RDAs. Regarding institutional framework, it is stated that there has been little progress on this area. In the report, it is also noticed that no progress has made about programming, monitoring and evaluation (EC, 2005: 101-102).

In 2006 Progress Report, as in 2004 and 2005 reports, Turkey is criticized about territorial organisation, regarding NUTS system. It is stated that most institutions in Turkey continue to use the traditional geographical regions as the main reference (EC, 2006a: 56). Regarding legislative framework, it is stress that there was some progress in the development of the legislative framework. The report has indicated that there was positive improvement about Development Agencies. In institutional framework and administrative capacity areas, it is stated that some progress about programming, financial management and control have made since from last report. The report indicates that there is a good progress about monitoring and evaluation, 
regarding Monitoring Information System. Overall, it is described that Turkey's alignment with the acquis in regional policy and coordination of structural instruments is modest.

Afterwards 2007 Progress Report, the title of territorial organization is not included in the progress report. Hence, there is no evaluation on this subject in subsequent progress reports. With regard legislative framework, it is mentioned that Turkey made progress, but also it is criticized that the law setting up RDAs has been challenged by a number of associations and preparations in this area are at an early stage. Also it is argued that funding for the two Development Agencies established in Izmir and Adana has been suspended pending the decision of the Constitutional Court on the legality of the legal basis for Development Agencies. The other fields that have made progress are institutional framework and financial management, control and audit. It is stated that there is very weak progress on administrative capacity and it is criticized that there is no progress about monitoring and evaluation. In general, Turkey's alignment with the acquis in this chapter is limited (EC, 2007: 57).

At the end of the year 2007, the second major development has been made by Turkish Government which is the establishment of Development Agencies with Law No: 5449 in November. This progress is mentioned in 2008 Progress Report (EC, 2008: 64). As regards programming, preparing Strategic Coherence Framework (SCF) is underlined as good progress in this area. It is also stated that there is some progress in monitoring and evaluation, financial management, control and audit. However, it is criticized that there is limited progress in institutional framework and administrative capacity.

In 2009 Progress Report, it is criticized that there is very weak progress in the following areas: administrative capacity, monitoring and evaluation, financial management, control and audit. Besides, it is noticed that progress was made in some areas, namely legislative framework, institutional framework, and programming. The major developments that were highlighted in the report are; implementing legislation on support for projects and activities from development agencies (November 2008) and Turkey's IPA Framework Agreement (December 2008), and establishment of Development Agencies in all provisional NUTS Level 2 regions (EC, 2009: 67-68).

In 2010 Progress Report (EC, 2010), represent a positive outlook. Similarly in the 2011 Progress Report, it is stated that progress was made in institutional framework, administrative capacity, programming, monitoring and evaluation, financial management, control and audit. It is the only exception that there is no progress in legislative framework. As regards institutional framework, the establishment of the High Council of Regional Development and the Regional 
Development Committee (RDC), the appointment of Secretaries-General in all 26 DAs and the preparation of regional plans in 24 of 26 NUTS Level 2 regions are welcomed (EC, 2011: 83-84).

Lastly, in 2012 Progress Report, as in 2010, there is a positive outlook in all areas. With regard legislative framework, the restructuring the Ministry of Transport, the Ministry of Environment and Forestry, the Ministry of Industry and Trade and the Ministry of Labour and Social Security are underlined. Similarly, as regards institutional framework, the establishment of Ministry of Environment and Urbanisation and the Ministry of Science, Industry and Technology are noticed. It is stated that there are also some progress in other areas. However, at the end of the report, as an overall assessment, it is noticed that 'preparations in this area are not very advanced' (EC, 2012: 70).

Considering the financial dimension of negotiation period, it can be see that after the full membership negotiations began in October 2005, there has been a substantial increase in TR-EU financial assistance budget. In the 2007-2013 period a new era has begun in the relations between EU and Turkey in terms of EU funds.

Figure 1: EU Budget Allocated to Turkey

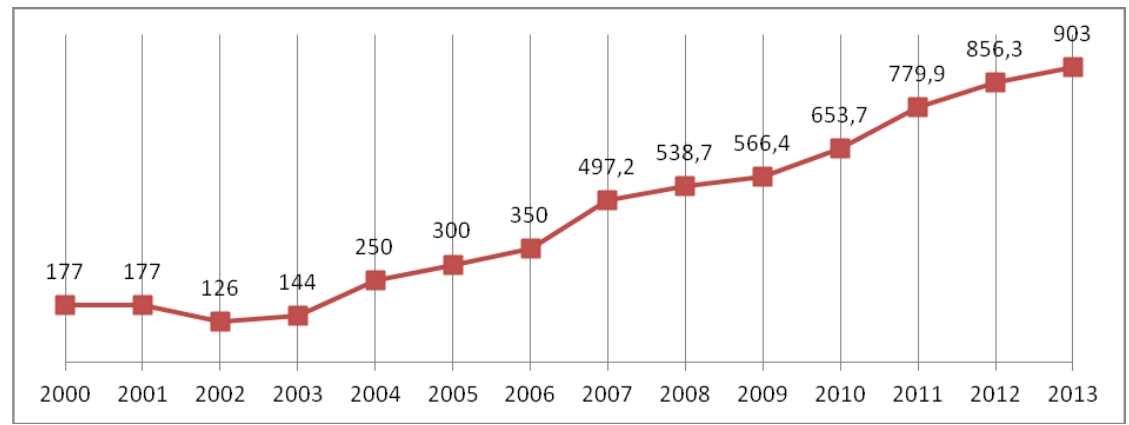

Source: Ministry for EU Affairs, http://www.ab.gov.tr

In the budget period 2007-2013, the mechanisms of financial assistance of EU to candidate and potential candidate countries are consolidated into a single instrument which is called Instrument for Pre-Accession Assistance (IPA). In this context, the candidate countries will be able to get support from the funds on the basis of 5 priorities: (I) Cohesion Assistance and Institutional Capacity, (II) Regional and Trans-boundary Cooperation, (III) Regional Development, (IV) Improvement of Human Resources, and (V) Rural Development (EC, 2006b: 85). For the budget period 2007-2013, about 10 Billion Euros has been allocated to candidate and potential candidate countries under the IPA. Considering the population and area size, 48.2 percent of this fund (4.8 Billion Euros) is allocated to 
Turkey for 2007-2013 (Ministry for EU Affairs, 2012: 7). The distribution of IPA according to its components is as follows:

Table 4: Turkey's 2007-2013 EU Fund According to IPA Components

\begin{tabular}{|l|r|}
\hline IPA Component & $\begin{array}{r}\text { Fund } \\
\text { (Million Euro) }\end{array}$ \\
\hline $\begin{array}{l}\text { I. Transition Assistance and } \\
\text { Institution Building }\end{array}$ & $1.667,5$ \\
\hline II. Cross-border Cooperation & 20,6 \\
\hline III. Regional Development & $1.778,4$ \\
\hline IV. Human Resources & 474,1 \\
\hline Development & 854,6 \\
\hline V. Rural Development & $\mathbf{4 . 7 9 5 , 2}$ \\
\hline Total &
\end{tabular}

Source: Ministry for EU Affairs, http://www.ab.gov.tr

It is important to mention that the contribution of these funds seems to be has little impact considering the size of Turkish economy. The fund allocated to Turkey cannot be considered as sufficient but Turkey is trying to utilize these funds with maximum effort. For 2007-2013, EU fund provided to Turkey under IPA is $€ 66$ per capita which is $€ 171$ for Bosnia \& Herzegovina and $€ 378$ for Montenegro (Ministry for EU Affairs, http://www.ab.gov.tr). However, the mechanisms and systems that these funds are more important; hence it introduces or supports systematic change at administrative level.

\section{Turning Points}

In the period of 8th FYDP, Turkey's accession and adaptation process to the EU has accelerated. It is expected that accession will have direct impact on Turkish regional policies. In this regard, in order to increase the efficiency of regional development in creating value added to both regional and national economies, designing new tools seems inevitable. Moreover, for Turkey, it is important to adapt a similar approach in regional development policy like the EU. This will lead to more effective exploitation of pre-accession financial assistance and eventually accelerate accession process. Following the Common Agricultural Policy (CAP), the regional policy of the EU is the second largest item of the EU budget. That means, although there is no compulsory directive or need about the transfer of the acquis on regional policy and structural instruments to internal legislation, regional policy will provide the largest financial assistance, and thus will contribute to national economic growth more than any other chapter of the acquis. 
Figure 2: Milestones in Turkish Regional Policy: the EU Impact

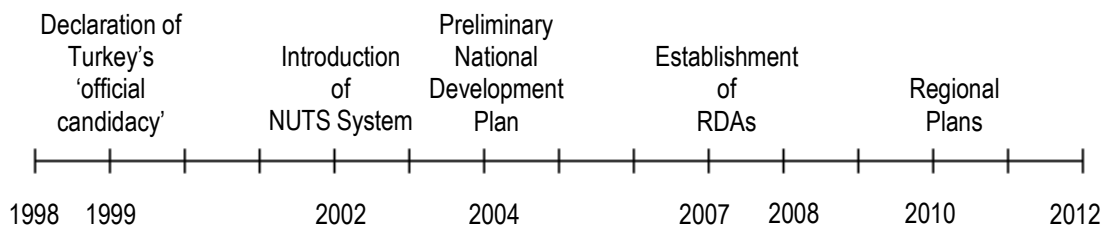

In this context, various critical steps have been taken relating to adaptation to acquis. First of all, in 2002, the new regional classification was introduced compatible with the EU's NUTS classification in Turkey by the Law No 2002/4720. In 2004, as another important step, the PNDP which was prepared by the SPO submitted to the EU. Another important step is the introduction of RDAs in Turkey by the Law No 5449. In this chapter, these efforts will be evaluated in detail.

\subsection{Realization of the NUTS System}

In the period of 8th FYDP, the EU accession process of Turkey also makes radical changes in regional development policies and implementation possible. These changes are: (i) the necessary infrastructure is being created at the central and local levels in order to prepare for the structural funds that could be used after membership, and (ii) the environment required for an active and participatory regional development policy is being prepared (DPT, 2007: 55). In this context a critical step was taken in the 8th FYDP period and The Nomenclature of Territorial Units for Statistics (NUTS), which enables the determination of the framework for regional development policies, the collection of regional statistics and the creation of a comparable statistical database harmonized with the EU regional statistics system was realized at three levels in 2002 (Ertugal, 2005: 6; DPT, 2007: 56, Başbakanlık, 2002). The decision of the Turkish Government (no: 2002/4720) related to the implementation of NUTS was published in the Official Gazette of the Republic of Turkey (date: 09.22.2002, no: 24884) and was put into practice. According to this framework, 12 Nomenclature of Territorial Units (NTU) were defined as Level-1, 26 NTU were defined as Level-2, and 81 NTU (provinces) were defined as Level-3. The cabinet also agreed on that the NUTS will be the basis for regional policy. 
Figure 3: NUTS Level 2 Regions

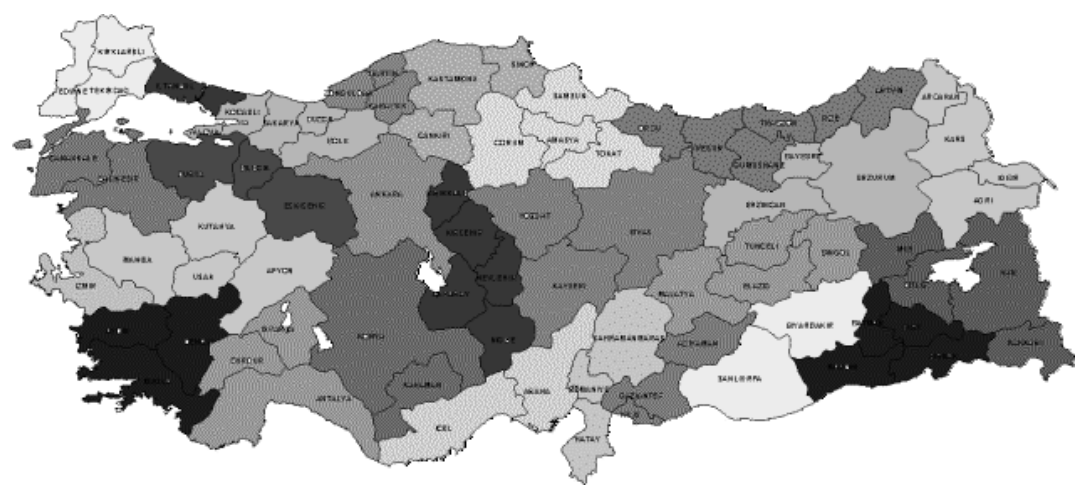

Source: DPT

\subsection{Learning to Programme: Preliminary National Development Plan}

In 1999 Helsinki Summit, Turkey was declared as a candidate country. In Helsinki Summit, it is decided that 'Turkey is a candidate State destined to join the Union on the basis of the same criteria as applied to the other candidate States. Building on the existing European Strategy, Turkey, like other candidate States, will benefit from a pre-accession strategy to stimulate and support its reforms.' (DPT, 2003b: i). Following this decision, the Accession Partnership with Turkey was adopted and the National Programme for the Adoption of the Acquis (NPAA) was approved by the Government of Turkey. The EC also requested from Turkey to prepare a Preliminary National Development Plan (PNDP), as with other candidate countries. As a result of this, with the coordination of the SPO Under-Secretariat, the PNDP was prepared. This plan, which is co-financed by EU financial support is an integrated plan in countrywide. The main difference of this plan from previous development plans is that this plan has a strong financial aspect and the responsibilities are clearly defined.

Turkey's first PNDP aimed to form the basis for the use of the financial assistance towards economic and social cohesion to be provided by the EU within the framework of Turkey-EU relations, during the 2004-2006 period. The legal bases of the pre-accession financial assistance for Turkey are Council Regulation (EC) No 390/2001 of 26 February 2001 and Council Regulation (EC) No 2500/2001 of 17 December 2001. It is aimed that during the PNDP period, preaccession financial assistance shall be used in an effective way and establishment of the necessary infrastructure shall be initiated for the utilization of structural funds after accession. For this purpose, four development axes / pillars were determined in the PNDP. These are (DPT, 2003b: iv): 
1. Enhancing the Competitiveness of Enterprises

2. Developing the Human Resources and Increasing the Employment

3. Improvement of Infrastructure Services and Environmental Protection

4. Increasing the Economic Power of Regions, Reducing the Interregional Development Disparities, and Accelerating Rural Development

The main objective of PNDP was to prepare to the EU funds. Turkey has not been supported through the PHARE, ISPA and SAPARD funds, from which the candidate countries benefit. Currently, Turkey is supported by the EU funds that are aggregated under the headline of 'Pre-Accession Financial Assistance for Turkey'. To benefit from the mentioned funds, Turkey prepared the PNDP that has also been prepared by the other candidate countries, which was pre-requested by the European Commission (Dulupçu \& Sungur, 2006).

\subsection{Establishment of Regional Development Agencies}

Another turning point in terms of regional development policies is the establishment of RDAs. On 25 January 2006, as an important step, the legislation for the formation of RDAs was accepted (Law No: 5449).

In the establishment of RDAs, the NUTS system was based on the establishment of RDAs and NUTS Level 2 regions were decided to establishment of RDAs. Total of 26-Development Agencies were established in all provisional NUTS Level 2 regions. Firstly, as of July 2006, with decision of Council of Ministers, No: 2006/10550 Izmir Development Agency (NUTS Level 2 TR31 Region) and Çukurova Development Agency (NUTS Level 2 TR62 Region) were established and began functioning. The decisions on the establishment of RDAs were published in the Official Gazette in 2008 and 2009 and all of them began operations. 
Table 5: NUTS Level 2 Regions and Regional Development Agencies

\begin{tabular}{|c|c|c|}
\hline REGION & INCLUDED PROVINCES & CENTRE \\
\hline TR31 & İzmir & İzmir \\
\hline TR62 & Adana, Mersin & Adana \\
\hline TR10 & İstanbul & İstanbul \\
\hline TR52 & Karaman, Konya & Konya \\
\hline TR83 & Amasya, Çorum, Samsun, Tokat & Samsun \\
\hline TRA1 & Bayburt, Erzincan, Erzurum & Erzurum \\
\hline TRB2 & Bitlis, Hakkâri, Muş, Van & Van \\
\hline TRC1 & Adıyaman, Gaziantep, Kilis & Gaziantep \\
\hline TRC2 & Diyarbakır, Şanlıurfa & Diyarbakır \\
\hline TRC3 & Batman, Mardin, Şırnak, Siirt & Mardin \\
\hline TR21 & Edirne, Kırklareli, Tekirdağ & Tekirdağ \\
\hline TR22 & Balıkesir, Çanakkale & Balıkesir \\
\hline TR32 & Aydın, Denizli, Muğla & Denizli \\
\hline TR33 & Afyonkarahisar, Kütahya, Manisa, Uşak & Kütahya \\
\hline TR41 & Bilecik, Bursa, Eskişehir & Bursa \\
\hline TR42 & Bolu, Düzse, Kocaeli, Sakarya, Yalova & Kocaeli \\
\hline TR51 & Ankara & Ankara \\
\hline TR61 & Antalya, Burdur, Isparta & Isparta \\
\hline TR63 & Hatay, Kahramanmaraş, Osmaniye & Hatay \\
\hline TR71 & Aksaray, Kırıkkale, Kırşehir, Nevşehir, Niğde & Nevşehir \\
\hline TR72 & Kayseri, Sivas, Yozgat & Kayseri \\
\hline TR81 & Bartın, Karabük, Zonguldak & Zonguldak \\
\hline TR82 & Çankırı, Kastamonu, Sinop & Kastamonu \\
\hline TR90 & $\begin{array}{l}\text { Artvin, Giresun, Gümüşhane, Ordu, Rize, } \\
\text { Trabzon }\end{array}$ & Trabzon \\
\hline TRA2 & Ağrı, Ardahan, Iğdır, Kars & Kars \\
\hline TRB1 & Bingöl, Elazı̆̆, Malatya, Tunceli & Malatya \\
\hline
\end{tabular}

Source: DPT.

Turkey benefits from IPA since 2007 and there is a regional development dimension with total budget of 1.778,4 billion Euros, as seen from Table 4 . However, this budget is not directly related with RDAs. RDA like institutions were 
established as 'service unions' (the name given by the SPO) with financial assistances between 2004 and 2006 depending PNDP.

At the beginning, the government and bureaucrats thought and established RDAs to provide a preparation to Structural Funds. However, they became a kind of a part of national planning when negotiations blocked. In other words, today, RDAs became a domestic policy tool instead of European policy. Nonetheless the newly emerged RDAs have some criticisms and insufficiencies. For example; the act on the RDAs was approved without sufficient participation of local actors, particularly the formal partner of the RDAs. Similarly insufficient information was given to local actors about the PNDP, which has reduced the project-preparing capacity of localities. Moreover, we can observe the low level of awareness in the local units of the central government about the PNDP. In addition provinces as administrative bodies are still affective compared to RDAs. Because central budget is still distributed according to provincial system through various ministries.

When considering the theory behind the establishment of RDAs, it is possible to say that RDAs are policy and implementation bodies in accordance with 'bottomup' approach, as 'new regionalism' suggests. Although RDAs are not compulsory, Turkey has accepted this model as changing in regional development understanding. However, the determination of the geographical borders of the RDAs under the NUTS system is somehow mysterious. There is no clear approach in the determination of the borders of the RDAs. The SPO, most likely, utilized the findings of previous researches such as functional regions study of the 1980s (DPT, 1982; 2000b: 29; Filiztekin, 2008: 95) and attractive centres of the 2000s (DPT, 2007) instead of employing a bottom-to-up approach.

\subsection{Resistence of Centralism}

As mentioned above, after the Law No: 5449 was approved, two RDAs (İzmir and Çukurova) were established and began functioning in 2006. However, CHP $^{2}$ (opposition party) was filed to the Constitutional Court for cancellation and suspension of execution of some articles of Law No. 5449. Its ground is shown as 'Development agencies are neither public institutions nor private companies, but they are using public resources and there is a serious contradiction to the Constitution'. In addition Development Agencies is based on classification of NUTS Level 2 and CHP is argued that such a classification could not be based in the organization of public institutions because in the Constitution of the Republic, only 81 provinces are identified as administrative units. And CHP has argued that classifications which are based on different levels are contrary to the Constitution (Akdenizli, 2007). The existing Development Agencies have stopped their activities

\footnotetext{
${ }^{2}$ Republican People's Party
} 
nearly during a year because of the cases which is claimed to the Constitutional Court and the Council of State. The decision of the Constitutional Court about Law is ended with positive results so Izmir and Çukurova Development Agencies, which were established in March 2008, were re-started operations. Then there is no any legal obstacle in front of the establishment of Development Agencies. As a result of this, during the years 2008 and 2009, RDAs were established and began operations in the remaining of 24 regions.

Development agencies is exposured to serious criticism because of this issue was not explained to the public sufficiently and so public awareness is failed. RDAs are being implemented in EU during long years and they were asked to put into practice in Turkey which is a candidate country of EU. But this situation is perceived as EU's preparation of Turkey to the state system. In addition, the act on the RDAs was approved without sufficient participation of local actors, particularly the formal partners of the RDAs. Similarly insufficient information was given to local actors about the PNDP, which has reduced the project-preparing capacity of localities. Moreover, we can observe the low level of awareness in the local units of the central government about the PNDP.

\section{Conclusion: Quo Vadis?}

The $21^{\text {st }}$ Chapter is the most contributing subject of the acquis to the economic and social development of Turkey in the EU full membership process. This chapter becomes the basic finance area of pre-full membership period. Therefore, the $21^{\text {st }}$ Chapter of the acquis determines the vision of not only regional but also national development. In this context, Turkey's negotiation process with the EU, by and large, will profoundly shape the future orientation of regional policy in the country.

Turkey, in order to benefit efficiently from the gains linked to establishing full adaptation to the acquis, should well comprehend and know the acquis on regional policy, and well evaluate and interpret the critical points it bears.

The acquis under the $21^{\text {st }}$ chapter has basically two interconnected dimensions: technical and political. The technical dimension consists of restructuring the SPO and regional programming. In this regard, the newly established RDAs in Turkey cannot be the reflection of the regional level as a suitable policy scale, but be that of mere Europeanization, if radical measures on decentralization are not taken by and large. It is important to mention that the geographical scale of Turkey enforces the SPO to create a more decentralized system of governance and economic planning; but once again, decentralization has been born as a part of centralization. Moreover, the regions, particularly at the NUTS Level 2, are created for the sake of the accession without consulting to the locals in the existing provinces or providing enough public awareness. 
To sum up the EU adaptation process has three main implications for the regional policies of Turkey:

- Restructuring and questioning at the regional level

- The devolution of the responsibilities of field units of central government to local administrations and municipalities

- Increase and development in local financial capacity and capabilities.

The ongoing regional programmes co-funded by the EU have already proved that there is a critical lack of regional policymaking capacity at the regional level. In other words, unprepared regionalization would probably cause under- or misutilization of limited resources. This issue brings us to the political dimension of chapter $21^{\text {st }}$. The lack of regional awareness, along with insufficient regional policymaking incentives, could not accelerate the accession process unless a new decision-making process is included to the system: devolution. Accountability and power autonomy should settle within the RDAs and provincial administrations. Otherwise, regions would be inactive partners of the regional policy, and the regional programmes would turn into centrally imposed development plans, as they have always been. 


\section{References:}

Akdenizli, D., (2007), “Kalkınma Ajansları Neden Gerekli?”, (2 September 2007), Radikal.

Amin, A. \& Thrift, N. (1994), Globalization, Institutions and Regional Economic Development in Europe, Oxford University Press, Oxford.

Amin, A. \& Thrift, N., (1995), "Institutional Issues for the European Regions: From Markets and Plans to Socioeconomics and Powers of Association”, Economy And Society, 24(1), pp. 41-65.

Avrupa Komisyonu Türkiye Temsilciliği (2000), Avrupa Birliği Bölgesel Politika: Yerli Kaynakların Ekonomik Gelişme İçin Harekete Geçirilmesi, Ankara.

Başbakanlık, (2002), 2002/4720 Sayılı Bölgesel İstatistiklerin Toplanması, Geliştirilmesi, Bölgelerin Sosyo-Ekonomik Analizlerinin Yapılması, Bölgesel Politikaların Çerçevesinin Belirlenmesi ve Avrupa Birliği Bölgesel İstatistik Sistemine Uygun Karşılaştırılabilir İstatistikî Veri Tabanı Oluşturulması Amacıyla Ülke Çapında İstatistikî Bölge Birimleri Sınıflandırılmasının Tanımlanmasına ilişkin Karar, (22 September 2002), 24884 Sayılı Resmi Gazete.

Başbakanlık, (2003), Avrupa Birliği Müktesebatının Üstlenilmesine İlişkin Türkiye Ulusal Programı, (24 July 2003), 25178 Sayılı Resmi Gazete.

Brasche, U., (2001), Avrupa Birliği'nin Bölgesel Politikası ve Türkiye'nin Uyumu, (trans.) by H. Cansevdi, İktisadi Kalkınma Vakfı Yayınları, İstanbul.

Burfisher, M.E., Robinson, S. \& Thierfelder, K. (2004), Regionalism: Old and New, Theory and Practice, International Food Policy Research Institute, Markets, Trade and Institutions Division Working Paper No: 65.

DPT (1962), Birinci Beş Yıllık Kalkınma Planı, DPT, Ankara.

DPT (1967), İkinci Beş Yıllık Kalkınma Planı, DPT, Ankara.

DPT (1972), Üçüncü Beş Yıllık Kalkınma Planı, DPT, Ankara.

DPT (1978), Dördüncü Beş Yıllık Kalkınma Planı, DPT, Ankara.

DPT (1982), Türkiye'de Yerleşme Merkezlerinin Kademelenmesi: Ülke Yerleşme Merkezleri Sistemi, DPT, Ankara.

DPT (1985), Beşinci Beş Yıllık Kalkınma Planı, DPT, Ankara.

DPT (1990), Altıncı Beş Yıllık Kalkınma Planı, DPT, Ankara.

DPT (1996), Yedinci Beş Yıllık Kalkınma Planı, DPT, Ankara.

DPT (2000a), Uzun Vadeli Strateji ve Sekizinci Beş Yıllık Kalkınma Planı, DPT, Ankara.

DPT (2000b), Sekizinci Beş Yıllık Kalkınma Planı Bölgesel Gelişme Özel İhtisas

Komisyonu Raporu, DPT, Ankara.

DPT (2003a), Türkiye Iç̧in Katılım Ortaklı̆̆ Belgesi, Ankara.

DPT (2003b), Ön Ulusal Kalkınma Planı (2004-2006), Ankara.

DPT (2003c), Illler ve Bölgeler Itibarıla GSYIH'daki Gelişmeler (1987-2000), DPT, Ankara. DPT (2007), Dokuzuncu Beş Yıllık Kalkınma Planı, DPT, Ankara. 
Dulupçu, M.A. \& Sungur, O. (2006), “Adaptation Problem of Turkey to the Regional Policies Within the Process of the EU Membership: Dilemmas and Opportunities", International Conference on The Changes and Transformations in the Socio-Economic and Political Structure of Turkey Within the EU Negotiations, Dumlupinar University, March 16-18, Kütahya, pp. 297-316.

Dulupçu, M.A., (2005), “Regionalization for Turkey: An Illusion or a Cure?”, European Urban and Regional Studies, 12(9), pp. 99-115.

Dulupçu, M.A., (2006), "Bölgesel Politikalar Kopyalanabilir mi? Bölgeselleş(tir)me (Yönetim) Karşısında (Yeni) Bölge(sel)cilik (Yönetişim)”, Bölgesel Kalkınma ve Yönetişim Sempozyumu, ODTU, September 7-8, Ankara, pp. 233-255.

Dulupçu, M.A., Gül, H. \& Okçu, M., (2013), Regional and Local Perspectives in Economic Development in Turkey, Turkey in the New Millennium: A Critique of Political, Social and Economic Transformations, Kamalak, İ. \& Gül, H. (eds), Lambert Academic Publishing, pp. 263-311.

Emek, U., (2004), Understanding Structural Reforms in Turkey, Turkey and the EU Enlargement: Processes of Incorporation, Griffits R.T \& Özdemir, D. (eds), Istanbul Bilgi University Press, Istanbul, pp. 103-128.

Ertugal, E., (2005), "Strategies For Regional Development: Challenges Facing Turkey on the Road to EU Membership", Turkish Policy Quarterly, 4(3), pp. 63-86.

European Commission (EC) (1998), Regular Report from the Commission on Turkey's Progress Towards Accession, 4 November, Brussels.

European Commission (EC) (1999), Regular Report from the Commission on Turkey's Progress Towards Accession, 13 October, Brussels.

European Commission (EC) (2000), Regular Report from the Commission on Turkey's Progress Towards Accession, 8 November, Brussels.

European Commission (EC) (2001), Regular Report on Turkey's Progress Towards Accession, 13 November, Brussels.

European Commission (EC) (2002), Regular Report on Turkey's Progress Towards Accession, 6 October, Brussels.

European Commission (EC) (2003), Regular Report on Turkey's Progress Towards Accession, 8 November, Brussels.

European Commission (EC) (2004), Regular Report on Turkey's Progress Towards Accession, 9 October, Brussels.

European Commission (EC) (2005a), Turkey 2005 Progress Report, 9 November, Brussels.

European Commission (EC) (2005b), Proposal for a Council Decision-On the Principles, Priorities and Conditions contained in the Accession Partnership with Turkey, 9 September, Brussels.

European Commission (EC) (2005c), 2005 Enlargement Strategy Paper, 9 September, Brussels.

European Commission (EC) (2006a), Turkey 2006 Progress Report, 8 November, Brussels. 
European Commission (EC) (2006b), Council Regulation No: 1085/2006, Official Journal of European Union, Date: 31.07.2006

European Commission (EC) (2007), Turkey 2007 Progress Report, 6 November, Brussels.

European Commission (EC) (2008), Turkey 2008 Progress Report, 5 November, Brussels.

European Commission (EC) (2009), Turkey 2009 Progress Report, 14 October, Brussels.

European Commission (EC) (2010), Turkey 2010 Progress Report, 9 November, Brussels.

European Commission (EC) (2011), Turkey 2011 Progress Report, 12 October, Brussels.

European Commission (EC) (2012), Turkey 2012 Progress Report, 10 October, Brussels.

Filiztekin, A., (2008), Türkiye'de Bölgesel Farklar ve Politikalar, TÜSİAD Yayınları No: TÜSİAD-T/2008-09/471, Istanbul.

Florida, R., (1995), “Toward The Learning Region”, Futures, 27, pp. 527-536.

Göksu, S. (2000), Küreselleşme ve Planlama Sonu, Dünya Şehircilik Günü 23. Kolokyumu 3.Bin Yılda Küreselleşme ve Planlama, Yıldız Teknik University Press, Istanbul.

Hettne, B., (2005), "Beyond the 'New' Regionalism”, New Political Economy, 10(4), pp. 543-571.

IRE - Innovating Regions in Europe (IRE), <www.innovating-regions.org>.

Keating, M., (1998), The New Regionalism in Western Europe, Territorial Restructuring and Political Change, Edward Elgar Publishing, Aldershot.

Loewendahl-Ertugal, E., (2005), "Europeanisation of Regional Policy and Regional Governance: The Case of Turkey”, European Political Economy Review, 3(1), pp. 18-53.

Lovering, J., (1999), “Theory Led by Policy? The Inadequacies of the 'New Regionalism' in Economic Geography Illustrated from the Case of Wales", International Journal of Urban and Regional Research, 23, pp. 379-395.

Ministry for EU Affairs (2012), 2012 Progress Report prepared by Turkey, December.

OECD (1986), Documentation for the Review of Regional Problems and Policies in Turkey, Directorate for Science, Technology and Industry, England.

OECD (1988), Regional Problems and Policies in Turkey, Paris.

OECD (2009a), Policy Brief, March.

OECD (2009b), How Regions Grow: Trends and Analysis, Paris. 